\title{
Een random-coëfficiënten-model voor het voorspellen van de beroepenstructuur van bedrijfstakken
}

Citation for published version (APA):

Borghans, L., \& Heijke, J. A. M. (1994). Een random-coëfficiënten-model voor het voorspellen van de beroepenstructuur van bedrijfstakken. Researchcentrum voor Onderwijs en Arbeidsmarkt, Faculteit der Economische Wetenschappen. ROA Working Papers No. 1 https://doi.org/10.26481/umarow.1994001

Document status and date:

Published: 01/01/1994

DOI:

10.26481/umarow.1994001

Document Version:

Publisher's PDF, also known as Version of record

\section{Please check the document version of this publication:}

- A submitted manuscript is the version of the article upon submission and before peer-review. There can be important differences between the submitted version and the official published version of record.

People interested in the research are advised to contact the author for the final version of the publication, or visit the DOI to the publisher's website.

- The final author version and the galley proof are versions of the publication after peer review.

- The final published version features the final layout of the paper including the volume, issue and page numbers.

Link to publication

\footnotetext{
General rights rights.

- You may freely distribute the URL identifying the publication in the public portal. please follow below link for the End User Agreement:

www.umlib.nl/taverne-license

Take down policy

If you believe that this document breaches copyright please contact us at:

repository@maastrichtuniversity.nl

providing details and we will investigate your claim.
}

Copyright and moral rights for the publications made accessible in the public portal are retained by the authors and/or other copyright owners and it is a condition of accessing publications that users recognise and abide by the legal requirements associated with these

- Users may download and print one copy of any publication from the public portal for the purpose of private study or research.

- You may not further distribute the material or use it for any profit-making activity or commercial gain

If the publication is distributed under the terms of Article $25 \mathrm{fa}$ of the Dutch Copyright Act, indicated by the "Taverne" license above, 


\section{Een random-coëfficiënten-model voor het voorspellen van de beroepenstructuur van bedrijfstakken}

Lex Borghans en Hans Heijke

ROA-W-1994/1

Researchcentrum voor Onderwijs en Arbeidsmarkt

Faculteit der Economische Wetenschappen

Rijksuniversiteit Limburg

Maastricht, november 1994 


\section{CIP-GEGEVENS KONINKLIJKE BIBLIOTHEEK, DEN HAAG}

\section{Borghans, Lex}

Een random coëfficiënten model voor het voorspellen van de beroepenstructuur van bedrijfstakken/Lex Borghans en Hans Heijke. -Maastricht: Researchcentrum voor Onderwijs en Arbeidsmarkt, Faculteit der Economische Wetenschappen, Rijksuniversiteit Limburg. (Werkdocument/Researchcentrum voor Onderwijs en Arbeidsmarkt, ISSN 0922-4645; ROA-W1994/1)

Met lit. opg.

ISBN 90-5321-150-0

Trefw.: beroepen; Nederland; toekomst. 


\section{Inhoudsopgave}

Bladzijde

1 Inleiding 1

2 Het Athena-model 3

3 De desaggregatie van werkgelegenheidsvergelijkingen 5

4 De specificatie van beroepsvergelijkingen $\quad 7$

5 Random coëfficiënten $\quad 8$

6 De bedrijfstakken 12

$\begin{array}{lll}7 & \text { Een voorbeeld } & 16\end{array}$

8 Aanpassingen 19

9 Resultaten 21

10 Conclusies $\quad 24$

$\begin{array}{lr}\text { Literatuur } & 24\end{array}$ 



\section{Inleiding}

Om inzicht te krijgen in de arbeidsmarktperspectieven voor schoolverlaters met een bepaalde opleidingsachtergrond en meer algemeen om inzicht te krijgen in de ontwikkelingen op de arbeidsmarkt op een betrekkelijk laag aggregatieniveau, maakt het ROA om de twee jaar prognoses van vraag- en aanbod op de arbeidsmarkt. In dit werkdocument wordt ingegaan op het onderdeel van het gebruikte prognosemodel waarin de uitbreidingsvraag per beroepssegment wordt bepaald. Te zamen met de vervangingsvraag, waarover elders wordt gerapporteerd vormt de uitbreidingsvraag het aantal baanopeningen per beroepssegment ${ }^{1}$.

Bij het voorspellen van de toekomstige vraag naar bepaalde beroepen spelen twee aspecten een rol. Ten eerste kan als gevolg van de economische ontwikkeling het belang van de ene bedrijfstak toenemen terwijl een andere bedrijfstak in belang afneemt. Indien deze bedrijfstakken niet dezelfde beroepenstructuur hebben (wat doorgaans het geval is) zal deze verschuiving tussen bedrijfstakken ook consequenties hebben voor de totale vraag naar bepaalde beroepen. Daarnaast kan de beroepenstructuur binnen een bedrijfstak zich wijzigen door een geleidelijke substitutie van het ene beroep door het andere. Dit kan het gevolg zijn van technologische veranderingen, maar van conjuncturele invloeden. Het kan bijvoorbeeld het geval zijn dat tijdens een conjuncturele terugval van een bepaalde bedrijfstak bepaalde beroepen sneller verdwijnen dan andere, bijvoorbeeld vanwege het verschil in aanpassingskosten.

Voor het maken van prognoses met betrekking tot de vraag naar bepaalde beroepen is het derhalve nodig te beschikken over zowel een bedrijfssectormodel, waarmee de ontwikkelingen per bedrijfssector voorspeld kunnen worden als een model voor de beroepenstructuur van deze bedrijfstakken. Het ROA heeft besloten zelf geen bedrijfssectormodel te ontwikkelen, maar de voorspellingen van het Centraal Plan Bureau (CPB) met betrekking tot de werkgelegenheid per bedrijfstak, over te nemen. Hierbij wordt gebruik gemaakt van het bedrijfssectoren-model Athena van het CPB (1990). Het ligt immers voor de hand te veronderstellen dat een ad hoc door het ROA ontwikkeld multi-sector model niet dezelfde voorspelkwaliteit kan leveren als dit CPB-model. Verder heeft de aansluiting bij het CPB-model als voordeel dat de voorspellingen van het ROA betreffende de beroepenstructuur van bedrijfstakken, en afgeleid daarvan ook de opleidingsstructuur van beroepen, consistent zijn met de CPB-voorspellingen.

Op basis van de bedrijfssectorprognoses van het CPB kan, voor het voorspellen van de vraag naar bepaalde beroepen, volstaan worden met een model waarin de beroepenstructuur van de bedrijfssectoren wordt verklaard. De ontwikkeling van een dergelijk beroepenmodel brengt twee problemen met zich mee. Ten eerste moeten de afzonderlijke vergelijkingen zodanig geschat worden dat de som van deze vergelijkingen gelijk is aan de oorspronkelijke Athena-vergelijking. Er moet derhalve een specificatie van dit beroepenmodel worden gekozen, waarvoor (bij benadering) geldt dat aan deze aggregatie-eis is voldaan. Omdat de vergelijking aan enkele eisen moet voldoen, en doordat het Athena-model in groeivoeten is geformuleerd, is het echter moeilijk een specificatie te vinden die garandeert dat de voorspellingen op beroepsniveau overeenstemmen met de voorspellingen op

1. Over de opzet van andere onderdelen van het prognosemodel en voor het Informatiesysteem Onderwijs-Arbeidsmarkt wordt verslag gedaan in Dekker e.a. (1993). De meest recente prognoses zijn te vinden in ROA (1993a,b) en LDC (1993). 
bedrijfstak-niveau. Er zijn twee aanpakken mogelijk om toch consistentie te krijgen. Ten eerste kan voor een verdeelspecificatie gekozen worden, waarbij niet de absolute vraag naar een beroep, maar het aandeel van een beroep in het totaal berekend wordt, zodat de voorspellingen van de verdeling over beroepen in feite losstaan van de voorspellingen op bedrijfstakniveau. Ten tweede kan een specificatie gekozen worden waarbij de gelijkheid slechts bij benadering opgaat, en waarbij achteraf een correctie op de voorspellingen op beroepsnivau wordt aangebracht die zorgt voor consistentie.

Een tweede probleem bij de ontwikkeling van een beroepenmodel dat aansluit op het Athena-model betreft het feit dat beschikbare tijdreeksen voor de beroepenstructuur van bedrijfstakken zeer kort zijn en daardoor de schattingen op basis hiervan zeer onbetrouwbare resultaten kunnen geven. Voor de analyse van de beroepenstructuur van bedrijfssegmenten is men voor Nederland immers aangewezen op de Arbeidskrachtentelling (AKT) en de Enquête Beroepsbevolking (EBB) waarvan slechts acht jaren, 1979, 1981, 1983, 1985, 1988, 1989, 1990 en 1991 beschikbaar waren bij het schatten van het beroepenmodel. Door de korte tijdreeksen kan een eenmalige verandering in de vraag naar een bepaalde opleiding (eventueel veroorzaakt door een meetfout) grote effecten hebben op de geschatte coëfficiënten. Dit kan tot gevolg hebben dat bij de prognoses de vraag naar een bepaald beroep exponentieel gaat groeien en derhalve de andere beroepen van het toneel verdwijnen. Een oplossing kan gezocht worden in het vergroten van de steekproef door 'pooling'. Nadeel van deze aanpak is dat het hiervoor nodig is a priori uitspraken te doen over de samenhang van de parameters in verschillende bedrijfstakken. Doel van het beroepenmodel is immers om de specifieke aspecten van de veranderingen van de beroepenstructuur in kaart te brengen. Door een te sterke beperking van de parameterstructuur van het model gaat deze mogelijkheid verloren.

In Dekker, De Grip en Heijke (1988) werd het eerste beroepenmodel voor het ROA-informatiesysteem geformuleerd. Dit model bevatte lineaire vergelijkingen waarin beroepen gepooled werden over bedrijfssegmenten. De nadruk in deze studie lag op de selectie tussen diverse modelvarianten. In Peeters (1990) werd de prognosemethodiek van het beroepenmodel verder ontwikkeld. Hierbij lag het accent op de specificatie van het model en de econometrische problemen die zich hierbij voordoen. Er werd een model ontwikkeld waarbij altijd voldaan is aan de genoemde aggregatie-eis.

In de praktijk bleven er echter problemen met de stabiliteit van het model. In deze studie wordt daarom het voorspellen van de beroepenstructuur van bedrijfssectoren opnieuw onderzocht, waarbij dit maal het accent ligt op de stabiliteit van de parameterschattingen. Hierbij zal gebruik worden gemaakt van een random-coëfficiënten-model. In dit model zijn de parameterschattingen gebaseerd op zowel de gepoolde schattingen als de afzonderlijke ongepoolde schattingen. De uiteindelijke schatting wordt bepaald door een gewogen gemiddelde van beide schattingen, afhankelijk van hun betrouwbaarheid.

De methode die hier gebruikt wordt om het stabiliteitsprobleem op te lossen is het inbouwen van een conservatisme in de schattingen. De parameters in de afzonderlijke vergelijkingen (per beroep) kunnen namelijk gezien worden als afwijkingen van de werkgelegenheidsvergelijking voor de totale bedrijfstak. Door middel van een random-coëfficiënten-model kunnen dan parameters per beroep geschat worden die voortkomen uit een afweging van de onzekerheid met betrekking tot de parameters en de onzekerheid met betrekking tot de data. Parameterschattingen met een lage betrouwbaarheid worden gedeeltelijk teruggebracht tot een bepaalde gemiddelde parameterwaarde. Dit leidt ertoe dat met name bij kleine beroepen extreem hoge parameters niet snel meer zullen voorkomen en dat de te flexibele vergelijking in het geval van onbetrouwbare schattingen vrijwel geheel wordt vervangen door een model 
waarin de veranderingen in de vraag volledig worden bepaald door verschuivingen in de werkgelegenheid tussen bedrijfssectoren. Deze benadering sluit aan bij de praktijk insignificante en dus onbetrouwbare coëfficiënten op nul te stellen.

Omdat dit random-coëfficiënten-model niet los kan worden gezien van de modelspecificatie wordt ook hieraan enige aandacht geschonken. Hierbij wordt geprobeerd om het model qua structuur beter aan te passen aan het Athena-model van het CPB, dat immers de invoer van het beroepenmodel vormt. Dit wordt onder andere bereikt door de verklarende variabelen per bedrijfssector grotendeels samen te laten vallen met de variabelen die in Athena worden gebruikt.

In dit werkdocument wordt allereerst kort ingegaan op de opbouw van het Athena-model (paragraaf 2). Vervolgens wordt in paragraaf 3 en 4 ingegaan op de modelspecificatie. In paragraaf 5 wordt de opzet van het random-coëfficiënten-model uiteengezet. Vervolgens worden in paragraaf 6 de werkgelegenheidsvergelijkingen van de bedrijfssectoren in Athena besproken. In paragraaf 7 volgt dan, bij wijze van voorbeeld, een bespreking van twee beroepssegmenten uit de bedrijfssector 'overige industrie'. In paragraaf 8 wordt ingegaan op enkele specifieke aanpassingen die hebben plaatsgevonden bij het opstellen van prognoses voor de arbeidsmarkt in 1998 en in paragraaf 9 worden de prognoseresultaten gepresenteerd. Tenslotte volgen in paragraaf 10 enkele conclusies.

\section{Het Athena-model}

Het Athena-model is ontwikkeld door het Centraal Planbureau voor het verrichten van studies waarin de bedrijfssectorstructuur van de economische ontwikkeling een rol speelt (Zie CPB, 1990). Het model komt voort uit VINSEC (Draper, Nieuwenhuis en Tjan, 1987) en BETA (Eijgenraam en Verkade, 1988) en maakte naast de overheid onderscheid tussen dertien bedrijfstakken. Door een herindeling van de gebruikte bedrijfstakken is dit aantal thans veertien. Figuur 1 geeft een globaal overzicht van de onderlinge verbanden die in Athena gemodelleerd zijn. Voor het doel van deze studie is met name de werkgelegenheid relevant. Deze hangt in Athena sterk samen met de produktie. Deze twee grootheden hangen beide naast het arbeidsaanbod af van investeringen, afzet en de loonvoet.

Een belangrijk facet van het Athena-model is de jaargangen-produktiefunctie, die voor de vier industriële bedrijfstakken is gehanteerd. In deze produktiefunctie wordt rekening gehouden met de mogelijkheid dat kapitaal binnen een bedrijfstak niet homogeen is. Per soort kapitaal wordt een clay-clay-structuur verondersteld, maar vanwege aggregatie geldt dit verband niet meer op bedrijfstakniveau. De verschillende soorten kapitaal kunnen onderling verschillen in arbeidsintensiteit en winstgevendheid. Daardoor zal ook de levensduur verschillend zijn. Deze specificatie heeft als belangrijk gevolg dat de effecten van een loonsverandering op de arbeidsproduktiviteit minder drastisch zijn dan in de gebruikelijke aanpak.

Voor de niet-industriële bedrijfstakken is de hierboven beschreven jaargangen-produktiefunctie niet gehanteerd. Omdat in deze bedrijfstakken de produktie minder sterk aan de kaptiaalgoederenvoorraad is gekoppeld, is hier gekozen voor ad hoc specificaties die de relaties tussen de relevante factoren binnen de betreffende bedrijfstakken zo goed mogelijk beschrijven. In paragaaf 6 wordt een overzicht gegeven van deze factoren. 
Een zeer belangrijke rol voor de werkgelegenheid per bedrijfstak wordt in Athena gespeeld door de loonvoet. Verondersteld is dat de beslissingen van ondernemers om te investeren sterk afhangen van de loonvoet, omdat de loonvoet in grote mate het rendement bepaalt. Omdat de loonvoet relatief onafhankelijk is van buitenlandse factoren kan deze grootheid in de opzet van Athena gebruikt worden om de binnenlandse economie in evenwicht te brengen. Werkloosheid in Athena wordt dan ook voornamelijk veroorzaakt door een tekortschieten van deze evenwichttotstandbrengende functie van de loonvoet.

Figuur 1

De globale structuur van Athena (uit CPB, 1992, p. 4)

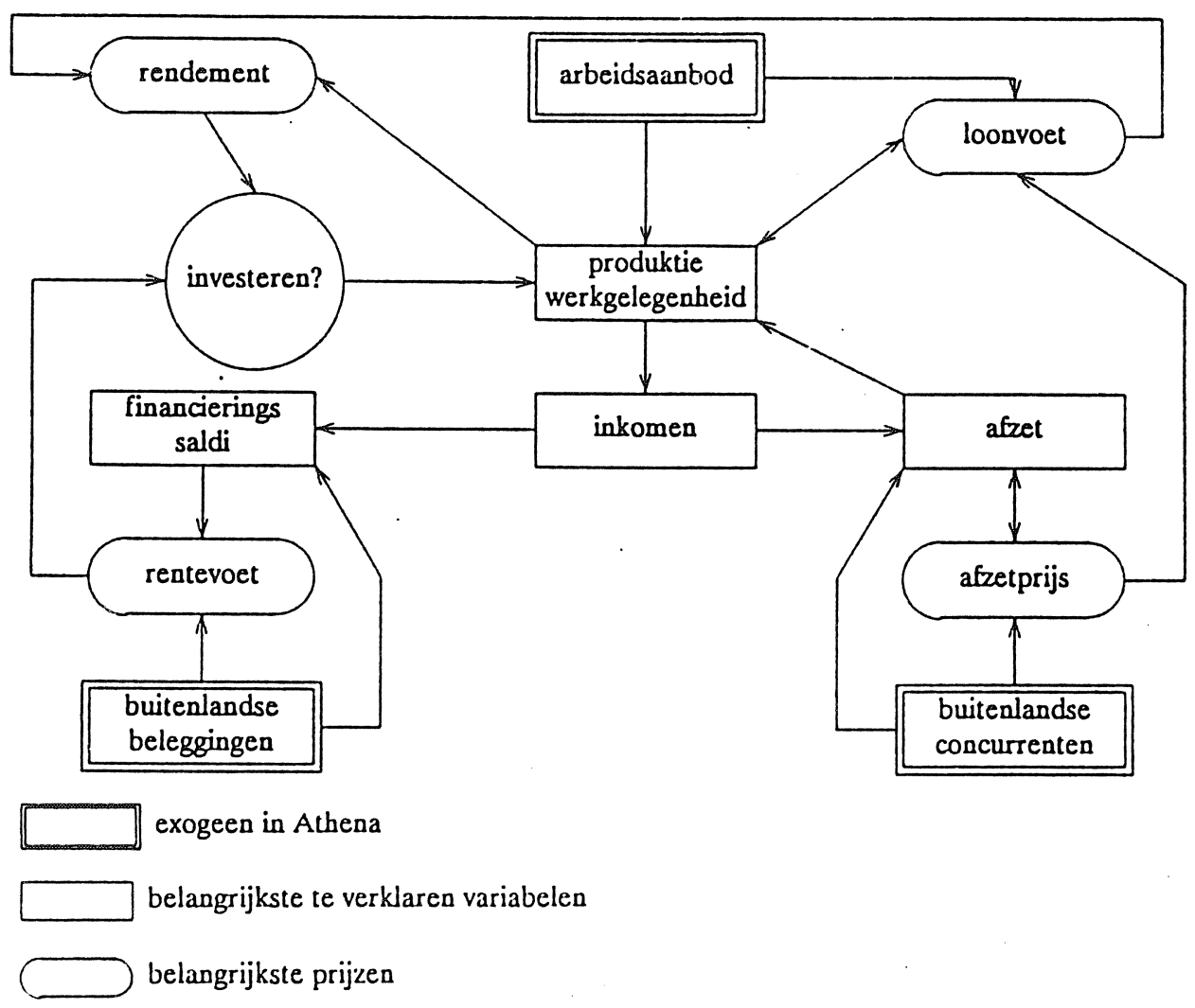

Vanuit de optiek van dit paper, waarin gekeken zal worden op welke wijze de werkgelegenheid per beroep zal veranderen als gevolg van sectorale verschuivingen en algemene macro-economische ontwikkelingen, lijkt het aannemelijk om de economische mechanismes die besloten liggen in het Athena-model, in eerste instantie toe te schrijven aan de onderliggende beroepsgroepen. Veranderingen in de productiestructuur en loonsveranderingen zullen in eerste instantie leiden tot wijzigingen in de werkgelegenheid per beroepsklasse in een bedrijfstak. De verbanden die in Athena gemodelleerd zijn kunnen dan ook het beste beschouwd worden als schattingen van het gemiddelde effect van deze economische impulsen op de totale werkgelegenheid in de bedrijfstak.

Voor het verbijzonderen van deze werkgelegenheidsprognoses naar beroep is het derhalve noodzakelijk deze geaggregeerde vergelijkingen weer te desaggregeren tot werkgelegenheidsverglijkingen per beroepsklasse. Het is dus niet zo dat feitelijk eerst de werkgelegenheid per bedrijfsklasse gedetermineerd wordt en pas dan bepaald wordt hoe deze werkgelegenheid verdeeld wordt over de 
beroepen. Voor een desaggregatie van de CPB-prognoses moet om die reden in feite gezocht worden naar een verbijzondering van de werkgelegenheidsvergelijking en niet van de werkgelegenheidsprognose. In dit paper zal geprobeerd worden vanuit dit gezichtsveld een beroepenmodel op te zetten. Een directe implicatie van dit uitgangspunt is dat voor de verklarende variabelen van het beroepenmodel in eerste instantie gekeken zal worden naar variabelen die ook in de geaggregeerde vergelijkingen van Athena zijn opgenomen. Als bepaalde variabelen een rol spelen in een aggregaat, dan moeten zij logischerwijs ook van belang zijn voor de vergelijkingen op een lager aggregatieniveau.

\section{De desaggregatie van werkgelegenheidsvergelijkingen}

In Athena wordt de werkgelegenheid in een bepaalde bedrijfstak steeds geformuleerd in groeivoeten:

$$
\dot{a}_{t}=\frac{a_{t}}{a_{t-1}}-1=\frac{a_{t}-a_{t-1}}{a_{t-1}}
$$

Waarbij a de werkgelegenheid (in volume) van een bepaalde bedrijfstak is. De werkgelegenheidsgroei is vervolgens lineair afhankelijk gesteld van enkele verklarende variabelen $X$, doorgaans ook groeivoeten.

$\dot{a}_{t}=X \beta+\epsilon$

Voor een analyse op gedesaggregeerd niveau dient een vergelijkbare vergelijking per beroep te worden opgesteld. Enkele eigenschappen die belangrijk zijn bij zo een gedesaggregeerde vergelijking zijn:

1) Het verdient de voorkeur dat de parameters van de vergelijkingen geen hoeveelheidsdimensie hebben. Immers, indien er enige dynamiek in de beroepenstructuur binnen een sector te verwachten is, kan het gebeuren dat een bepaald beroep sterk van omvang veranderd. Een parameter met een hoeveelheidsdimensie kan in zo een geval leiden tot zeer onwaarschijnlijke ontwikkelingen, en het is te verwachten dat de parameter niet stabiel zal zijn in de tijd, maar zal afhangen van de feitelijke hoeveelheidsontwikkeling.

2) Aangezien verklarende modellen van de beroepenstructuur altijd maar een zeer beperkte verklaring zullen geven, ligt het voor de hand te veronderstellen dat de laatst waargenomen beroepenstructuur zeer informatief is voor de toekomstige beroepenstructuur. Het is dan ook wenselijk een specificatie te hebben die niet de omvang van een beroep als zodanig, maar de veranderingen in die structuur verklaart.

3) Ten slotte dienen de voorspellingen per beroep samen op te tellen tot de voorspelling van de werkgelegenheid van de hele bedrijfstak, en mag de vraag per beroep niet negatief worden en niet groter worden dan de totale vraag in die bedrijfstak. Als fractie van het totaal dient de werkgelegenheid in een beroep dus tussen 0 en 1 te blijven. Indien deze consistentie niet aanwezig is, zijn er twee mogelijkheden. Als de consistentie met betrekking tot aggregatie niet gegarandeerd is, maar alle beroepen wel altijd positief zullen blijven, kan een correctie op de voorspellingen worden aangebracht door ze te vermenigvuldigen met een bepaalde factor. Zeker als de afwijkingen maar klein zijn, is dit een zeer bevredigende oplossing. Als echter beroepsaandelen ook negatief kunnen worden, dan is een dergelijke oplossing niet mogelijk.

In tabel 1 staan van vier mogelijke specificaties voor het beroepenmodel de eigenschappen vermeld. Ten eerste betreft dit de lineaire specificatie: 
$a^{\prime}=X \beta^{\prime}$

Een groot nadeel van deze vorm is de hoeveelheidsdimensie van de parameter. Als de exogene variabelen in de tijd constant zijn, dan zullen veranderingen die zij veroorzaken zich in absolute aantallen in een gelijkblijvende omvang voortzetten. De aantallen kunnen dan ook groter worden dan 1 of kleiner dan 0 . Omdat de Athena-hoofdvergelijking in groeivoeten is, is aggregatie-consistentie niet aanwezig. Bij een lineaire hoofdvergelijking zou deze consistentie (onder een parameterrestrictie) wel mogelijk zijn. Negatieve aantallen blijven echter ook dan voorkomen.

Ten tweede is er de gebruikelijke verdeelspecificatie, die ook is toegepast in Peeters (1990):

$\ln \left(\frac{a^{i}}{a^{\text {ref }}}\right)=X \beta^{i}$

waarin de werkgelegenheid in beroep $i$ voorspeld wordt ten opzichte van een referentieberoep (ref). Het voordeel van een verdeelspecificatie is dat deze niet de absolute aantallen voorspelt, maar de verhouding tussen de beroepsaantallen. Om deze cijfers om te zetten naar absolute aantallen is de voorspelling van de vraag naar arbeid op bedrijfssectorniveau nodig. De voorspellingen zijn derhalve automatisch consistent met betrekking tot aggregatie. Ook zorgt de specificatie ervoor dat de aandelen tussen 0 en 1 blijven. De vorm kent echter ook enkele nadelen. Allereerst heeft de parameter $\beta$, ondanks de relatie met het referentieberoep, toch een hoeveelheidsdimensie. Bij een constante omvang van het referentie-beroep is immers het effect van een bepaalde verklarende variabele op de verandering van de werkgelegenheid in een beroep overal even groot en zal bij grotere beroepen $\beta$ doorgaans groter zijn. Verder voorspelt het model geen veranderingen, maar niveaus. Het kan daardoor voorkomen dat een voorspelling op een zeer korte termijn sterk afwijkt van de laatste waargenomen waarde, doordat deze waarde volgens het model een uitbijter is.

Ten derde bevat tabel 1 eigenschapen van een groeispecificatie:

$\dot{a}^{\prime}=\frac{a_{t}^{i}-a_{t-1}^{i}}{a_{t-1}^{\prime}}=X \beta^{\prime}$

Deze specificatie komt tegemoet aan de hierboven vermelde bezwaren van het verdeel-model. De parameter is dimensieloos en het model voorspelt veranderingen in plaats van niveaus. Een nadeel van deze specificatie is echter dat de aggregatie-consistentie niet meer hoeft te gelden. Met een parameterrestrictie is het mogelijk deze consistentie bij benadering te laten gelden in de buurt van de huidige beroepenstructuur, maar als de beroepenstructuur drastisch gaat veranderen kan deze benadering tekort schieten. Omdat de voorspelde aantallen echter altijd groter dan 0 zullen blijven, is het mogelijk deze inconsistentie te corrigeren door een vermenigvuldigingsfactor toe te passen.

Deze vorm combineert de voordelen van het verdeelmodel en het groeimodel. De enige nadelen zijn de complexe vorm, waardoor de parameters moeilijker te interpreteren zijn, en het feit dat de specificatie niet symmetrisch is met betrekking tot de referentie-categorie. In feite wordt voor de referentie-categorie een iets afwijkende specificatie verondersteld, zodat de keuze van deze referentie kleine gevolgen voor de voorspellingen kan hebben. 
Ten slotte een groei-verdeel-specificatie:

$\left(\frac{\dot{a}}{a^{\text {ref }}}\right)=\frac{\frac{a_{t}^{i}}{a_{t}^{\text {ref }}}-\frac{a_{t-1}^{i}}{a_{t-1}^{\text {ref }}}}{\frac{a_{t-1}^{i}}{a_{t-1}^{\text {ref }}}}=X \beta^{i}$

Tabel 1

Overzicht eigenschappen van enkele specificaties

\begin{tabular}{|c|c|c|c|c|c|c|c|c|}
\hline & \multirow[t]{2}{*}{ referentie } & \multirow{2}{*}{$\begin{array}{l}\text { hoeveel- } \\
\text { heids- } \\
\text { dimensie }\end{array}$} & \multirow[t]{2}{*}{$\Delta$} & \multirow[t]{2}{*}{$>0$} & \multirow[t]{2}{*}{$<1$} & \multirow[t]{2}{*}{ aggregatie } & \multicolumn{2}{|c|}{ herverdeling } \\
\hline & & & & & & & nodig & mogelijk \\
\hline $\begin{array}{l}\text { lineair model } \\
\text { verdeelmodel } \\
\text { groei-model } \\
\text { groei-verdeel-model }\end{array}$ & $\begin{array}{l}\text { nee } \\
\text { ja } \\
\text { nee } \\
\text { ja }\end{array}$ & $\begin{array}{l}\text { ja } \\
\text { ja } \\
\text { nee } \\
\text { nee }\end{array}$ & $\begin{array}{l}\text { nee } \\
\text { nee } \\
\text { ja } \\
\text { ja }\end{array}$ & $\begin{array}{l}\text { nee } \\
\text { ja } \\
\text { ja } \\
\text { ja }\end{array}$ & $\begin{array}{l}\text { nee } \\
\text { ja } \\
\text { nee } \\
\text { ja }\end{array}$ & $\begin{array}{l}\text { nee } \\
\text { ja } \\
\text { nee } \\
\text { ja }\end{array}$ & $\begin{array}{l}\text { ja } \\
\text { nee } \\
\text { ja } \\
\text { nee }\end{array}$ & nee \\
\hline
\end{tabular}

- $\mathrm{Er}$ is een restrictie mogelijk zodanig dat bij benadering aan de aggregatie-eis is voldaan

In paragraaf 5 zal blijken dat voor het gebruik van een random-coëfficiënt-model met name de eigenschap dat de specificatie geen hoeveelheidsdimensie in de parameter heeft van groot belang is. Om die reden blijft de keuze beperkt tot de laatste twee specificaties. Omdat het groei-model parameters heeft die beter te interpreteren zijn en vanwege de eenvoud van de specificatie, wordt in dit paper alleen het groeimodel besproken. Uitgevoerde exercities met beide modellen wijzen er overigens op dat de prognoseverschillen met het groei-verdeel-model slechts zeer klein zijn.

\section{De specificatie van beroepsvergelijkingen}

Zoals reeds gezegd in de inleiding, kan een betere aansluiting van het beroepenmodel bij het Athenabedrijfstakkenmodel bereikt worden, door in de vergelijkingen voor de vraag naar arbeid per beroep, verklarende variabelen op te nemen die ook in de vergelijking van de vraag naar arbeid voor de totale bedrijfssector zijn opgenomen. Uiteraard kunnen er ook additionele variabelen worden opgenomen, maar om de consistentie zoveel mogelijk te waarborgen moeten in ieder geval de belangrijkste variabelen van de hoofdvergelijking worden opgenomen. Bij gebruik van de groeivoetspecificatie geldt nu:

$\dot{a}_{t}^{\prime}=X_{1} \beta_{1}^{\prime}+X_{2} \beta_{2}+X_{3} \beta_{3}^{\prime}+\epsilon^{\prime}$

Er kunnen

(1) verklarende variabelen zijn die ook in de Athena-hoofdvergelijking zitten, maar die een andere coëfficiënt hebben $\left(X_{1}, \beta_{1}^{i}\right)$

(2) verklarende variabelen zijn die ook in de hoofdvergelijking zitten, en dezelfde coefficient hebben $\left(X_{2}, \beta_{2}^{\prime}=\beta_{2}\right)$.

(3) verklarende variabelen zijn die niet in de hoofdvergelijking zijn opgenomen $\left(X_{3}, \beta_{3}^{i}\right)$ 
Vanwege de groeivoeten is, zoals reeds vermeld werd in paragraaf 3 , het niet mogelijk parameters te vinden die consistent zijn met de hoofdvergelijking uit Athena. Wel kan de Athena-vergelijking in een punt benaderd worden. Er moet dan geschat worden onder de restrictie dat

$$
\sum_{i} \beta_{1}^{\prime} * \frac{a^{\prime}}{a}=\beta_{1}
$$

en

$$
\sum_{i} \beta_{3}^{\prime} * \frac{a^{\prime}}{a}=0
$$

Bij groep (2) hoeft uiteraard een dergelijke restrictie niet te worden opgelegd, omdat de parameters reeds overeenkomen met de hoofdvergelijking. Als alle parameters in groep (2) zitten is er overigens sprake van een exacte aggregatie, maar is de verdeling over beroepen nauwelijks nog interessant te noemen. De parameters van (2) hoeven niet meer geschat te worden. (4.1) kan herschreven worden tot:

$\dot{a}^{\prime}=X_{1} \beta_{1}+X_{2} \beta_{2}+X_{1}\left(\beta_{1}^{\prime}-\beta_{1}\right)+X_{3} \beta_{3}^{\prime}+\epsilon^{\prime}$

en dus

$\dot{a}^{\prime}=\dot{a}+X_{1}\left(\beta_{1}^{\prime}-\beta_{1}\right)+X_{3} \beta_{3}^{\prime}+\epsilon^{\prime}$

Als $\dot{a}$ zelf ook een verklarende variabele is voor $\dot{a}_{i}$ dan leidt dit tot een vergelijking met als verklarende variabelen $X_{1}, X_{3}$ en $\dot{a}$. Omdat de parameter voor $X_{1}$ nu afwijkingen t.o.v. $\beta_{1}$ aangeeft, moeten alle parameters gemiddeld 0 zijn behalve de parameter voor $\dot{a}$ die gemiddeld 1 moet zijn. Als $\dot{a}$ zelf geen verklarende variabele is, en dus de bijbehorende parameter 1 is, kan de vergelijking

$\dot{a}^{\prime}-\dot{a}=X_{1}\left(\beta_{1}^{\prime}-\beta_{1}\right)+X_{3} \beta^{\prime}+\epsilon^{\prime}$

worden geschat.

Deze vergelijking zal als uitgangspunt worden genomen voor de analyse van de ontwikkeling van de beroepenstructuur per bedrijfssector in de volgende paragrafen. De veronderstelling die aan deze specificatie ten grondslag ligt is dus dat de beroepssegmenten in een bedrijfssector in principe dezelfde groei doormaken als de bedrijfssector zelf. De exogene variabelen $X_{1}$, en $X_{3}$ kunnen de oorzaak zijn van een afwijkende groei, maar deze afwijkingen dienen gemiddeld 0 te zijn om te voldoen aan de randvoorwaarde die het aggregatiecriterium oplegt. Tegenover beroepssegmenten met een meer dan gemiddelde groei staan dus altijd ook beroepssegmenten met een minder dan gemiddelde groei, bij een bepaalde waarde van de exogene variabelen.

\section{Random coëfficiënten}

Een van de belangrijkste technische problemen bij het voorspellen van de beroepenstructuur van bedrijfstakken in de Nederlandse situatie, is de relatief korte tijdreeks die ter beschikking staat. Hierdoor zullen parameterschattingen een vrij lage nauwkeurigheid (oftewel een grote standaardfout) te zien geven. Deze fouten in de geschatte parameters werken door in de voorspellingen, en aangezien er bij het voorspellen van de beroepenstructuur sprake is van een verdeling van de totale vraag per bedrijfssector over de beroepssegmenten impliceert dit dat een sterk afwijkende parameterschatting bij een beroep ook grote invloed kan hebben op andere beroepen. 
In de praktijk betekent dit dat het vaak voorkomt dat de parameters van een klein beroep, met relatief onbetrouwbare data in de tijdreeks, een extreem hoge parameterschatting opleveren. Deze extreem hoge schattingen leiden vervolgens tot een extreme groei van dit beroep, wat vervolgens leidt tot een afname in de omvang van de andere beroepen. Zo kan het voorkomen dat een beroep dat aanvankelijk zeer onbeduidend was, volgens de prognoses binnen enkele jaren het overgrote deel van de werkgelegenheid in de bedrijfstak voor zijn rekening neemt. Een voorbeeld hiervan komt aan de orde in paragraaf 7 .

Tot nog toe werden dit soort problemen opgelost door parameterschattingen die tot dergelijke onmogelijke resultaten leidden ad hoc of volgens een selectiecriterium op een vaste, meer realistische waarde (meestal 0) te zetten. Het probleem bij deze aanpak is dat het onduidelijk is wanneer een parameter te groot is. $\mathrm{Er}$ is een schemergebied van mogelijke parameter-uitkomsten, waarin er twijfel bestaat of een parameter nog betrouwbaar is of niet. Verder is, vooral bij dergelijke twijfelgevallen, de oplossing die gekozen werd nogal drastisch. Als een parameter zeer hoog uitvalt kan deze omvang welliswaar betwijfeld worden, de richting waarin de parameterwaarde wijst blijft echter informatief.

Naast de oplossing waarbij ongewenste parameterschattingen op nul worden gesteld, zijn er twee gebruikelijke methodes om met het probleem om te gaan. De eerste methode betreft zogenaamde pooling over beroepen of bedrijfstakken. Om het aantal waarnemingen waarop schattingen zijn gebaseerd te vergroten, wordt hierbij de veronderstelling geïntroduceerd dat een bepaalde parameter in een aantal gevallen dezelfde waarde heeft. Zo kan bijvoorbeeld verondersteld worden dat alle beroepen op dezelfde manier reageren op een bepaalde variabele, of dat een beroep binnen alle bedrijfssectoren op dezelfde manier reageert. Deze aanpak heeft echter twee nadelen. Ten eerste blijkt door deze pooling het probleem van de explosieve voorspellingen veelal toch nog niet te worden opgelost. Belangrijker is echter dat de oplossing noopt tot het introduceren van veronderstellingen die een groot deel van de te observeren dynamiek in de beroepenstructuur elimineren. Vanuit een theoretische optiek kan het welliswaar interessant zijn te zoeken naar een parameter die de invloed van, bijvoorbeeld arbeidstijdverkorting, op de werkgelegenheidstructuur weergeeft, maar juist bij prognoses van de beroepenstructuur van bedrijfssectoren, waar getracht wordt de verschuivingen per beroep in beeld te brengen is een dergelijke parameterrestictie erg verstarrend. Lindley (1994) waarschuwt dan ook voor de verleiding gebrek aan tijdreeksinformatie op te lossen door cross-sectie-analyse.

Een tweede oplossing zou zijn het verzamelen van langere tijdreeksen. Zeker vanuit de optiek van Lindey zou dit de voorkeur verdienen. Echter afgezien van het praktische probleem dat de data niet beschikbaar zijn en dus vele jaren gewacht zou moeten worden voordat voorspellingen gemaakt kunnen worden, heeft het gebruik van zeer lange tijdreeksen nog een theoretisch bezwaar. Net zoals het niet juist is te veronderstellen dat beroepen binnen elke bedrijfstak op dezelfde wijze reageren op bepaalde exogene variablen, zo is het ook niet juist te veronderstellen dat deze verbanden voor een beroep gedurende een lange reeks van jaren constant zijn gebleven. De arbeidsmarkt is voordurend onderhevig aan veranderingen, nieuwe technieken worden geïntroduceerd, en nieuwe beroepen en opleidingen onstaan terwijl anderen verdwijnen. In deze dynamische context ligt het niet voor de hand dat de relaties tussen de belangrijke grootheden ongewijzigd zullen blijven. Er zal voortdurend sprake zijn van veranderingen in de structuur.

Zowel lange tijdreeksen als brede cross-sections zijn dus niet onmiddellijk de oplossing van de voorspelproblemen bij de beroepenstructuur. Het door Swamy $(1970,1971)$ geïntroduceerde random- 
coëfficiënten-model biedt echter de mogelijkheid de gegevens van een dergelijke lange tijdreeks of brede cross-sectie toch te benutten, waarbij echter de starheid van het poolen over tijd of beroepen niet hoeft op te treden. In dit werkdocument zal deze random-coëfficiënten-aanpak worden gehanteerd. Vooralsnog wordt de analyse echter beperkt tot cross-sectie-data. Daarbij wordt veronderstelling gemaakt dat parameters constant zijn over de tijd.

In het random-coëfficiënten-model wordt expliciet rekening gehouden met het feit dat parameters een bepaalde mate van onbetrouwbaarheid hebben. De cross-sectie-informatie dient hierbij niet in de eerste plaats voor het schatten van de parameters, maar dient allereerst als referentiekader. Binnen een bedrijfstak wordt voor elk beroep de volgende vergelijking geschat:

$\dot{a}_{i}=\dot{X} \beta_{i}$

OLS-schatting van de parameters $\beta_{i}$ levert per beroep een schatting op. Deze $\hat{\beta}_{i}$ 's zullen onderling uiteenlopen. Deze spreiding wordt veroorzaakt door twee factoren. Allereerst zullen de werkelijke waardes van de parameter $\beta_{i}$ uiteenlopen. Deze afwijking die verondersteld wordt stochastisch te zijn wordt genoteerd met $\eta_{i}$. Als deze afwijking niet voorkomt, dan wordt voldaan aan de voorwaarde voor pooling en kan een schatting met pooling plaatsvinden. Deze restrictie werd echter juist te star bevonden. Ten tweede zal er extra spreiding ontstaan tussen de $\hat{\beta}_{i}$ 's doordat de parameterschattingen afwijken van de werkelijke waarde. Deze spreiding wordt aangegeven met $\boldsymbol{\varepsilon}_{\boldsymbol{i}}$. Beide bronnen van het optreden van spreiding leiden tot het volgende schattingsmodel:

$\beta_{i}=\bar{\beta}+\eta_{i}$

$\hat{\beta}_{i}=\beta_{i}+\epsilon_{i}$

waarin $\bar{\beta}$ de gemiddelde parameter voor alle beroepen is, $\beta_{i}$ de parameter voor beroep $i$, en $\hat{\beta}_{i}$ de schatting hiervan.

Er geldt dus dat:

$\hat{\beta}_{i}=\bar{\beta}+\eta_{i}+\epsilon_{i}$

De spreiding van de parameterschattingen wordt dus veroorzaakt door de spreiding van de parameters tussen de beroepen en de standaardfouten van de afzonderlijke OLS-schattingen. Verondersteld wordt dat beide spreidingen normaal verdeeld zijn met verwachting 0 :

$\eta_{i} \sim N\left(0, \Sigma_{\eta}\right)$

$\epsilon_{i} \sim N\left(0, \Sigma_{e, j}\right)$

Swamy (1970) toont aan dat per beroep de OLS-schatter de beste lineaire zuivere schatter (BLUE) blijft, maar dat voor de minimalisering van de gemiddelde (MSE) over alle beroepen deze OLS-schatter verbeterd kan worden. In dit geval is het optimaal om een gewogen gemiddelde te nemen van de OLSschatting en $\bar{\beta}$, de verwachte parameter voor een willekeurig beroep. Het optimale gewicht hangt af van de spreiding van deze parameters over de beroepen en van de standaard-fout van de OLS-schatting van het betreffende beroep: 
$\tilde{\beta}_{i}=\left(\Sigma_{\eta}^{-1}+\Sigma_{e, i}^{-1}\right)^{-1}\left(\Sigma_{\eta}^{-1} \bar{\beta}+\Sigma_{e, i}^{-1} \hat{\beta}_{j}\right)$

Als een parameterschatting voor een bepaald beroep zeer onnauwkeurig is, en de spreiding tussen de beroepen niet groot is, zal deze combinatie zeer dicht bij het groepsgemiddelde komen te liggen. De methode toont dus overeenkomsten met de praktijk van het vastzetten van bepaalde parameterschattingen. Het vastzetten van parameters gebeurt doorgaans echter alleen op basis van $t-$ waardes, die alleen afhangen van de standaardfout van de individuele schatting. De schattingskwaliteit van de gerestricteerde (of gepoolde) vergelijking wordt niet in deze beslissing betrokken. Dit is bij het random-coëfficiënten-model wel het geval. Verder is er doorgaans sprake van een keuze voor één van de twee extremen. Dit betekent dat men of de individuele schatting handhaaft óf bij de parameter geheel gelijk stelt aan de vaste waarde. Bij het random-coëfficiënten-model is deze overgang evenwel gradueel.

Om de methode operationeel te maken is er een schatting nodig van de covariantiematrix van de spreiding van parameters tussen beroepen $\left(\Sigma_{\eta}\right)$. Door voor ieder beroep een OLS-schatting uit te voeren kan op basis van de geschatte $\hat{\beta}$ 's een schatting worden gemaakt van de covariantie-matrix van de spreiding van $\hat{\beta}_{i}\left(S_{\beta}\right)$. Deze is op basis van de OLS-schattingen eenvoudig te schatten. Theoretisch is deze is gelijk aan $S_{\beta}=\Sigma_{\eta}+\Sigma_{e}$. Swamy (1970) toont aan dat $\hat{\Sigma}_{\eta}=S_{\beta}-\bar{W}$, (waarin $\bar{W}$ een (gewogen) gemiddelde is van de geschatte covariantie-matrices van de OLS-schattingen, $\left(\Sigma_{e}^{\prime}\right)$, een zuivere schatter van deze matrix is). Omdat deze schatter echter niet positief-semi-definiete matrices kan opleveren, introduceren De Crombrugghe en Dhaene (1991) een alternatieve schatter die wel altijd positief-semidefiniet is. Deze wordt gevonden door het iteratieve proces:

$$
\begin{aligned}
& F^{(1)}=S_{\beta} \\
& F^{(n)}=F^{(n-1)}\left(F^{(n-1)}+\bar{M}^{-1} S_{\beta}\right.
\end{aligned}
$$

Na convergentie levert

$$
F=\lim _{n \rightarrow \infty} F^{(n)}
$$

een schatter voor $\Sigma_{\eta}$ die altijd positief-semi-definiet is.

In een standaard random-coëfficiënten-model moet ook $\bar{\beta}$ geschat worden. Een voor de hand liggende schatter hiervoor is het (gewogen) gemiddelde van de OLS-schattingen voor $\beta_{i}$. In het hier gepresenteerde model is echter de waarde van $\bar{\beta}$ bekend op theoretische gronden. (4.2) geeft aan dat het (gewogen) gemiddelde van $\beta_{i}$ gelijk moet zijn aan de coëfficiënt van de Athena-bedrijfstakvergelijking. Na omschrijving volgens (4.6) houdt dit in dat $\bar{\beta}=0$ voor alle verklarende variabelen.

In paragraaf 4 werd afgeleid dat de parameters van de groei-specificatie gemiddeld gelijk aan 0 moeten zijn om te voldoen aan de aggregatie-eis. Het vastzetten van $\bar{\beta}$ op zijn theoretische waarde is echter minder sterk dan de consistentie-eis (4.2). Omdat het hier gaat om een stochastische eigenschap zal hierdoor alleen gemiddeld aan deze eis zijn voldaan. Vanwege de technische problemen van het daadwerkelijke opleggen van dit deterministisch verband, wordt in dit paper de consistentie beperkt tot deze stochastische variant. 
De aanname (5.2) dat de parameters van de vergelijking van een bepaald beroepssegment kunnen worden beschouwd als een afwijking van de gemiddelde parameter die voor alle beroepssegmenten geldt, heeft alleen betekenis als alle beroepssegmenten in principe ook parameterwaardes rondom een dergelijk gemiddelde kunnen hebben. Parameters met een hoeveelheidsdimensie, waarbij de parameterwaarde doorgaans groter zal zijn bij grotere beroepssegmenten zijn derhalve in strijd met deze aanname. Bij de gekozen groeispecificatie is dit echter niet het geval. Deze specificatie lijkt derhalve zinvol vanuit de optiek van het random-coëfficiënten-model.

\section{De bedrijfstakken}

De prognoses met betrekking tot veranderingen van de beroepenstructuur van bedrijfstakken worden, zoals reeds is vermeld, gebaseerd op bedrijfstakprognoses met het Athena-model van het CPB, om zo te komen tot werkgelegenheidsprognoses per beroepssegment. Om een goede aansluiting tussen het beroepenmodel en Athena te bewerkstelligen, worden de verklarende variabelen voor de beroepenstructuur van bedrijfstakken gekozen in overeenstemming met het Athena-model. In deze paragraaf komt aan de orde op welke wijze het CPB (1990) de werkgelegenheidsontwikkeling van de bedrijfstakken modelleerd. Op grond hiervan wordt bekeken welke verklarende variabelen in aanmerking komen om te worden opgenomen in het beroepenmodel. In de volgende paragraaf zal vervolgens de gehanteerde methodiek aan de hand van een voorbeeld worden toegelicht.

Oorspronkelijk telde de Athena-classificatie, exclusief de overheid, 14 bedrijfstakken. Recentelijk zijn in deze classificatie enkele wijzigingen aangebracht. De bedrijfstak 'textiel- en kleding-industrie' is samengevoegd met 'overige industrie' tot een nieuwe bedrijfstak 'overige industrie'. Verder is 'aardolieindustrie en openbare nutsbedrijven' opgesplitst in twee aparte bedrijfstakken 'aardolie-industrie' en 'openbaar nut'. Ten slotte is 'bank en verzekeringswezen' los gemaakt van 'overige tertiair'.

De data met betrekking tot de verdeling van de werkgelegenheid binnen een bedrijfstak over beroepen zijn afkomstig van de AKT en de EBB van het CBS. De bij het ROA beschikbare data zijn echter nog gebaseerd op de oude Athena-indeling. Dit betekent dus dat er voor de drie wijzigingen binnen het Athena-model aanpassingen moeten worden aangebracht. Voor de samenvoeging van 'textiel en kleding-industrie' en 'overige industrie' kan bij de CBS-data eenzelfde samenvoeging plaatsvinden. Door deze samenvoeging achteraf is echter wel de nauwkeurigheid van de data verminderd. In de data die door het CBS ter beschikking zijn gesteld, zijn immers de aantallen die onder de 2.500 liggen weggelaten en zijn de aantallen afgerond. Bij een opsplitsing in twee bedrijfstakken zullen hierdoor meer cijfers verloren gaan dan bij berekening voor een grote bedrijfstak.

De opsplitsing van 'aardolie-industrie' en 'openbaar nut' levert vooralsnog geen problemen op. In het Athena-model hebben beide bedrijfstakken dezelfde werkgelegenheidsvergelijking gekregen. In de prognoses voor beroepen zullen deze twee bedrijfstakken dan ook als één sector behandeld worden. Wel zullen de prognoses van het CPB met betrekking tot deze bedrijfstakken moeten worden geaggregeerd.

Een vergelijkbare situatie ontstaat bij de afsplitsing van het bank- en verzekeringswezen. Doordat de benodigde data met betrekking tot de beroepenstructuur van deze nieuwe bedrijfstakken niet aanwezig zijn, zullen ook hier de voorspellingen van het CPB geaggregeerd moeten worden. 
Hier volgt een opsomming van de gebruikte verklarende variabelen per bedrijfstak:

Industriële bedrijfstakken

VG Voedings- en genotmiddelenindustrie

Ol Overige industrie (bevat dus ook textiel- en kledingindustrie)

$\mathrm{CR}$ Chemische industrie

ME Metaalindustrie

De vergelijkingen voor de werkgelegenheid in de industriële bedrijfstakken sluit aan bij de jaargangenproduktietechnologie. Er wordt onderscheid gemaakt tussen de lange-termijn- ontwikkeling en de kortetermijn-dynamiek.

De vergelijkingen voor de lange-termijn-ontwikkeling zijn uitgedrukt in logaritmen en verklaren de niveaus. Deze hangen af van:

- produktiecapaciteit $y^{*}$ van de toegevoegde waarde tegen factorkosten in het prijspeil waarvoor $p y=1$;

- reële loonvoet IIpy per arbeidsplaats, waarin py prijsindex van de toegevoegde waarde tegen factorkosten;

- aantal contractuele uren per arbeidsjaar $h$;

- jaartal $t$.

Deze vergelijking bevat zowel 'embodied' (via produktie-blok) als 'disembodied' technologische vooruitgang.

De korte-termijn-ontwikkeling van de werkgelegenheidsgroei is geformuleerd in groeivoeten en hangt af van:

- de vertraagde werkgelegenheidsgroei $\left(\mathfrak{a}_{-1}\right)$;

- de lange termijn werkgelegenheidsgroei en de vertraging hiervan $\left(\mathfrak{a}^{*}, \mathfrak{a}_{-1}^{*}\right)$;

- de groei van de bezettingsgraad en zijn vertraging $\left(\stackrel{\leftrightarrow}{q},^{\circ} \stackrel{\circ}{-1}_{1}\right)$;

- de vertraagde bemanningsgraad $\left(\ln q a_{-1}\right)$;

- de vertraagde bezettingsgraad $\left(q_{-1}\right)$.

Landbouw (LA)

Bij de landbouw is er een dominerende trendmatige daling van het aantal zelfstandigen. Hierbij spelen de werkgelegenheidsmogelijkheden buiten de landbouw een belangrijke rol. De groei wordt verklaard door:

- de vertraagde groei $\left(\stackrel{a}{-1}_{-1}\right)$;

- de werkgelegenheid en de vertraging hiervoor ( $\left.a w * q, a w * q_{-1}\right)$;

- een constante.

Energie (RN): aardolie-industrie en openbaar nut

De werkgelegenheid in de energie is vrijwel constant. Alleen de arbeidstijd (continuebedrijf) en de trend (uitbreiding produktie) zijn van belang. De verklarende variabelen zijn: 
- vertraagde groei $\left(\bar{a}_{1}\right)$;

- het vertraagde aantal contractueel gewerkte uren per arbeidsjaar $\left(\dot{h}_{-1}\right)$;

- constante.

Bouwnijverheid en woningbezit (BO, WO)

De bouw is zeer conjunctuurgevoelig. Daardoor is het moeilijk de directe effecten van de produktie op de werkgelegenheid te schatten. Daarom wordt zowel een korte-termijn- als een lange-termijnwerkgelegenheidsgroei-functie gegeven. Deze bevatten:

- groei binnenlandse afzet $(x-b)$;

- prijsindex ( $1 / p y$, alleen in de lange termijn-vergelijking);

- ontwikkeling produktieve uren per jaar (dus zonder vorst) (atp);

- vertraagde werkgelegenheid $\left(a w * q_{-1}\right)$ (alleen korte termijn);

- vertraagde bemanningsgraad $\left(q a_{-1}\right)$ (alleen korte termijn).

Voor de sector woningbezit is er een aparte vergelijking die afhangt van de groei van de toegevoegde waarde en een trend voor de stijging van de arbeidsproduktiviteit.

Handel (HA)

Ook in de handel wordt de lange termijn van de korte termijn onderscheiden. De verklarende variabelen zijn:

- groei bruto toegevoegde waarde tegen factorkosten $\left(\dot{y}_{-1}\right.$ in de lange termijn. In de korte termijn ook zonder vertraging en met 2 jaar vertraging);

- prijsindex (1/py);

- vertraagd verschil gemiddeld rendement en rente op overheidsleningen, alleen in de korte termijn;

- bemanningsgraad $\left(q a_{-1}\right)$, alleen korte termijn;

- constante.

Vervoer (VE)

De vergelijking voor vervoer lijkt op die van de handel, alleen heeft arbeidstijdverkorting hier wel invloed.

De vergelijking bevat de volgende verklarende variabelen:

- groei bruto toegevoegde waarde tegen factorkosten $\left(\dot{y}_{-1}\right.$ in de lange termijn. In de korte termijn ook zonder vertraging);

- prijsindex (1/py);

- ontwikkeling aantal contractuele arbeidsuren per jaar $(h)$, alleen lange termijn;

- vertraagd verschil gemiddeld rendement en rente op overheidsleningen, alleen in de korte termijn, met een vertragingsprocess;

- bemanningsgraad $\left(q a_{-1}\right)$, alleen korte termijn;

- constante.

Rest van de tertiaire diensten (RT)

Bij de rest van de tertiaire diensten zijn de volgende variabelen opgenomen:

- groei bruto toegevoegde waarde tegen factorkosten $(\dot{y})$; 
- prijsindex (1/pj);

- ontwikkeling aantal contractuele arbeidsuren per jaar $(\dot{h})$, alleen lange termijn;

- vertraagd verschil gemiddeld rendement en rente op overheidsleningen, alleen in de korte termijn, met een vertragingsproces;

- bemanningsgraad $\left(q a_{-1}\right)$, alleen korte termijn;

- constante.

\section{Kwartaire diensten (KW)}

De werkgelegenheidsvergelijking voor de kwartaire diensten bevat de variabelen:

- vertraagde groei werkgelegenheid, alleen korte termijn $\left(a_{-1}\right)$;

- groei volume toegevoegde waarde $(\dot{y})$;

- ontwikkeling contractuele uren $(\dot{h})$;

- bemanningsgraad (alleen korte termijn);

- constante.

Voor de overheidssector is geen aparte vergelijking opgenomen. Bij de CPB-prognoses wordt de werkgelegenheidsontwikkeling bij de overheid exogeen bepaald. Omdat er van de gebruikte data slechts zeer korte tijdreeksen beschikbaar zijn, kunnen onmogelijk alle verklarende variabelen die gebruikt worden voor de verklaring van de vraag naar arbeid per bedrijfsklasse worden opgenomen in de vergelijking per beroep. Verder is een groot aantal verklarende variabelen slechts van belang voor de korte-termijn-dynamiek van de vraag naar arbeid. Omdat in het beroepenmodel de middellange termijn centraal staat, kunnen deze variabelen makkelijk achterwege gelaten worden. Het betreft hier vooral de vertraagde variabelen. Ook loonontwikkelingen zijn buiten de analyse gehouden, omdat de CPBloonvoorspellingen alleen sector-lonen betreffen, en geen informatie verschaffen over de loonontwikkeling per beroep.

De variabelen die gebruikt zullen worden in het beroepenmodel zijn:

- De werkgelegenheidsgroei per bedrijfstak in werkzame personen $\left(a_{w p}\right)$, en als verklarende variabelen:

- De groei van de produktiecapaciteit per bedrijfstak $\left(\dot{y}^{*}\right)$;

- De ontwikkeling van het aantal contractuele uren per arbeidsjaar per bedrijfstak $(h)$;

- De groei van de bruto toegevoegde waarde per bedrijfstak $(\dot{y})$;

- De groei van de binnenlandse afzet $(\dot{x}-b)$ voor de bouw (BO);

- De ontwikkeling van het aantal produktieve uren per jaar (afp) voor de bouw (BO);

- Het werkloosheidspercentage $(a w * q)$ voor de gehele economie.

In tabel 1 staan de gebruikte verklarende variabelen per bedrijfstak aangegeven. Tabel 2 geeft een overzicht van de parameterwaardes die deze verklarende variabelen bij de werkgelegenheidsvergelijkingen van Athena hebben.

Te zamen met de geschatte effecten per beroepssegment geven deze parameters het totale werkgelegenheidseffect van deze variabelen op de vraag naar arbeid per beroepssegment per bedrijfstak. Omdat in het beroepenmodel een aantal bedrijfstakken uit de vernieuwde Athena-indeling zijn samengenomen bevat deze tabel enkele bedrijfstakken die niet in tabel 1 voorkomen. 


\begin{tabular}{|c|c|c|c|c|c|c|c|}
\hline sectoren & constante & $\dot{y}^{*}$ & $\dot{h}$ & $\dot{y}$ & $\dot{x}-b$ & atp & $a w * q$ \\
\hline VG (voeding) & $d$ & $d$ & $d$ & & & & \\
\hline textiel \& overige & $d$ & $d$ & $d$ & & & & \\
\hline CR (chemie) & $d$ & $d$ & $d$ & & & & \\
\hline ME (metaal) & d & d & $\checkmark$ & & & & \\
\hline LA (landbouw) & $d$ & & & & & & $d$ \\
\hline raffinage en openbaar nut & $d$ & & $d$ & & & & \\
\hline BO (bouw) en WO (woningen) & $d$ & & & & 9 & $\checkmark$ & \\
\hline HA (handel) & $d$ & & & $d$ & & & \\
\hline VE (vervoer) & $\mathscr{d}$ & & $\checkmark$ & 1 & & & \\
\hline BV (banken) en AT (overige tertiair) & 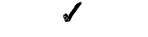 & & $d$ & $\checkmark$ & & & \\
\hline KW (kwartair) & $\mathscr{d}$ & & d & $d$ & & & \\
\hline overheid & $d$ & & & & & & \\
\hline
\end{tabular}

Tabel 2

Parameters in het Athena-model

\begin{tabular}{|c|c|c|c|c|c|c|c|}
\hline & C & $\dot{y}^{*}$ & $\dot{h}$ & $\dot{y}$ & $\dot{x}-b$ & atp & $a w * q$ \\
\hline VG (voeding) & 0,868 & $-0,142$ & & & & & \\
\hline Ol (textiel \& overige) & & 0,448 & $-0,260$ & & & & \\
\hline CR (chemie) & & 0,200 & 0 & & & & \\
\hline ME (metaal) & & 0,697 & $-0,150$ & & & & \\
\hline LA (landbouw) & $-1,563$ & & & & & 0,350 & \\
\hline raffinage & 0,457 & & $-0,467$ & & & & \\
\hline openbaar nut & 0,457 & & $-0,467$ & & & & \\
\hline BO (bouw) & $-1,867$ & & & & 0,77 & $-0,56$ & \\
\hline WO (woningen) & -2 & & & 1 & & & \\
\hline HA (handel) & $-0,704$ & & $-0,182$ & 0,682 & & & \\
\hline VE (vervoer) & $-0,340$ & & $-0,367$ & 0,399 & & & \\
\hline BV (banken) & $-0,640$ & & $-0,376$ & 0,453 & & & \\
\hline AT (overige tertiair) & $-0,136$ & & & 0,736 & & & \\
\hline KW (kwartair) & $-0,403$ & & $-0,359$ & 1 & & & \\
\hline
\end{tabular}

\section{Een voorbeeld}

In paragraaf 5 werd een beschrijving gegeven van het random-coëfficiënten-model dat is gehanteerd om prognoses te maken van de arbeidsmarktontwikkelingen per beroepssegment. Het voordeel van deze methode, vergeleken met de eerder gehanteerde schattingstechnieken, is het conservatieve karakter van deze methodiek. Omdat de beschikbare tijdsreeksen nogal kort zijn bevatten de schattingen bij een gebruikelijke aanpak veel onzekerheid. In deze paragraaf wordt op basis van een voorbeeld getoond hoe het gehanteerde model deze schattingsonzekerheid reduceert.

Als voorbeeld is gekozen voor twee beroepssegmenten in de bedrijfsector 'overige industrie'. Deze bedrijfssector bevat tevens, zoals in paragraaf 6 uiteengezet de vroegere bedrijfssector 'textiel- en 
kledingindustrie'. De beroepssegmenten die onder de loep worden genomen zijn 'lagere textielberoepen' (ROA-beroepencode 321) en 'lagere commerciële beroepen' (ROA-beroepencode 621). Vanwege de textielindustrie die in deze branche is vertegenwoordigd, zijn er veel personen werkzaam met een lager textielberoep. Er zijn echter slechts weinig personen werkzaam met een lagere commerciële functie.

Figuur 2

De historische en voorspelde ontwikkeling van lagere textielberoepen en lagere commerciële beroepen in 'overige industrie'2

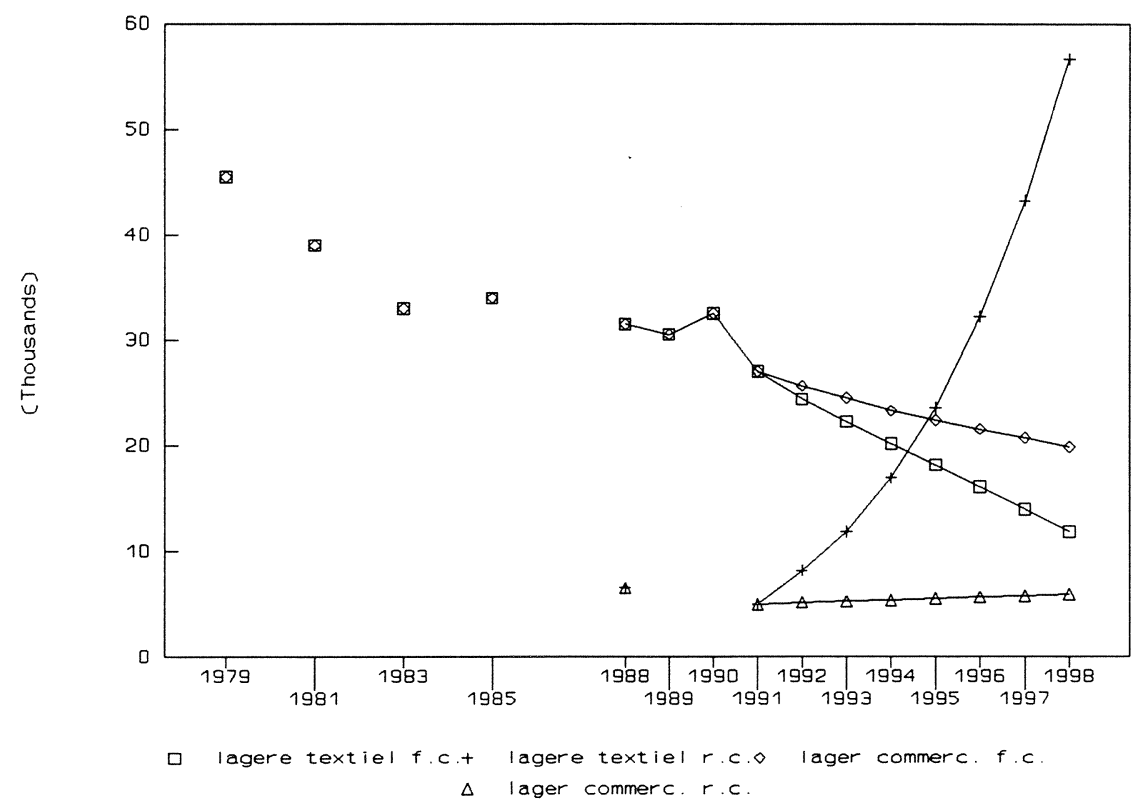

Verder geeft de tabel de prognoses voor deze beroepssegmenten in 1998 aan op basis van zowel het standaard model (zonder random-coëfficiënten) als het random-coëfficiënten-model. Volgens de prognoses van het vaste-coëfficiënten-model zouden de lagere commerciële beroepen een gigantische groei doormaken tot 56.000 personen. De aantallen werkzame personen met lagere textielberoepen zouden dalen tot 12.000 . Bij het random-coëfficiënten-model zijn deze voorspelde veranderingen veel minder drastisch. De lagere commerciële beroepen stijgen tot 6.000 , terwijl de lagere textielberoepen een daling tot 19.000 doormaken. Figuur 2 geeft een beeld van de historische en de voorspelde ontwikkelingen van beide beroepssegmenten voor beide schattingsmodellen.

In tabel 3 wordt getoond dat zowel de parameter van de trendvariabele als van het aantal gewerkte uren relatief zeer onzeker zijn. Hierdoor is het efficiënt om voor de voorspellingen een parameter te gebruiken die dichter bij het gemiddelde over alle beroepen (dat is 0 ) ligt. In tabel 5 wordt de covariantie-structuur van de parameters in de betreffende bedrijfstak gegeven. De onderlinge variantie van deze parameters is aanmerkelijk kleiner dan de variantie van de volgens het standaardmodel geschatte parameters voor de lagere commerciële beroepen, zodat de uiteindelijke randomcoëfficiënten-schatting bij dit beroepssegment dicht bij $0 \mathrm{komt}$ te liggen.

2. In dit figuur zijn aantallen beneden 5.000 weggelaten. 
Tabel 3

Parameterschattingen van standaardmodel en random-coëfficiënten-model (standaard-fouten van de parameters tusen haakjes)

\begin{tabular}{|c|c|c|c|}
\hline & trend & $\begin{array}{l}\text { produktie- } \\
\text { capaciteit }\end{array}$ & $\begin{array}{l}\text { gewerkte } \\
\text { uren }\end{array}$ \\
\hline \multicolumn{4}{|l|}{ standaard-model: } \\
\hline Lagere textielberoepen & $\begin{array}{c}-0,047 \\
(0,019)\end{array}$ & $\begin{array}{c}-0,512 \\
(0,480)\end{array}$ & $\begin{array}{c}-1,565 \\
(1,562)\end{array}$ \\
\hline Lagere commerciële beroepen & $\begin{array}{c}0,511 \\
(0,223)\end{array}$ & $\begin{array}{c}-0,098 \\
(5,626)\end{array}$ & $\begin{array}{c}23,99 \\
(18,291)\end{array}$ \\
\hline random-coëfficiënten-model: & & & \\
\hline Lagere textielberoepen & $-0,039$ & 0,145 & $-1,818$ \\
\hline Lagere commerciële beroepen & 0,043 & $-0,162$ & 2,036 \\
\hline
\end{tabular}

Bij lagere textielberoepen is de onzekerheid van de parameter-schattingen veel kleiner, zodat hier de reductie in de schattingen veel geringer is. Hoewel de voorspelde veranderingen bij de lagere commerciële beroepen aanvankelijk veel groter waren, voorspelt het random-coëfficiënten-model bij de lagere textiel-beroepen meer verandering, omdat deze voorspellingen betrouwbaarder zijn. Naarmate het moeilijker wordt op basis van de beschikbare data een uitspraak te doen over de veranderingen van een beroepssegment zal de voorspelmethodiek voor dit beroepssegment dus dichter bij het scenario komen dat de veranderingen van het beroep gelijk zijn aan de veranderingen van de gehele bedrijfstak.

Tabel 4

Covariantie-matrix van de parameters in de bedrijfssector 'overige industrie'

\begin{tabular}{lrrr}
\hline & trend & $\begin{array}{c}\text { produktie- } \\
\text { capaciteit }\end{array}$ & $\begin{array}{l}\text { gewerkte } \\
\text { uren }\end{array}$ \\
& & & \\
Trend & 0,004 & 0,062 & 9,772 \\
prod.cap. & $-0,017$ & $-0,780$ & 0,208 \\
gew. uren & & & \\
\hline
\end{tabular}

De tekens van de geschatte effecten zijn in overeenstemming met de verwachtingen over het verschil tussen een beroep in de directe produktie (lagere textielberoepen) en een beroep in de overhead (lagere commerciële beroepen). Deze verwachting is dat een vergroting van de produktiecapaciteit een positieve invloed heeft op het produktieberoep en een negatieve invloed op het overhead-beroep. Dit negatieve teken betekent dat de groei bij grotere produktiecapaciteit kleiner is dan gemiddeld in de bedrijfstak. Bij vergroting van het aantal gewerkte uren verminderd (in personen gemeten) het aantal directe produktiewekers en wordt de bijdrage van de indirecte arbeid groter. Het is overigens opmerkelijk dat de parameter van de produktiecapaciteit bij de lagere textiel-beroepen alleen positief is bij de random-coëfficiënten-schatting. Deze verandering van teken wordt veroorzaakt door de structuur van de covariantie-matrix van de parameters. Door de negatieve correlatie met beide andere 
grootheden wordt als compensatie van het groter worden (dat wil zeggen het minder negatief worden) van de twee overige verklarende variabelen ook de parameter van de produktiecapaciteit groter.

\section{Aanpassingen}

De in paragraaf 5 beschreven methodiek voor het schatten van de veranderingen van de beroepenstructuur van bedrijfstakken is gebruikt om prognoses te maken van de werkgelegenheidsontwikkeling per beroepssegment voor de periode 1993-1998. Deze prognoses maken deel uit van de arbeidsmarktprognoses voor 1998 van het ROA (ROA, 1993a,b). Op grond van de beschikbare data en vanwege enkele specifieke problemen in bepaalde beroepssegmenten of bedrijfssectoren moest bij het opstellen van de prognoses voor 1993-1998 echter op enkele plaatsen een aanpassing van de methodiek plaatsvinden. Dit betreft allereerst de omzetting van de arbeidsvolumes uit de CPBprognoses naar aantallen werkzame personen zoals die in de AKT en EBB gehanteerd worden. Verder waren er aanpassingen nodig vanwege de door het CBS gehanteerde ondergrens bij het beschikbaar stellen van data. Andere aanpassingen hebben betrekking op inhoudelijke situaties. In deze paragraaf worden deze aanpassingen beschreven en wordt kort ingegaan op de verdere desaggregatie van de werkgelegenheidsprognoses per beroepssegment naar prognoses per beroepsklasse. In de volgende paragraaf zullen de resultaten van de gemaakte voorspellingen besproken worden.

\section{Omrekening naar aantallen personen}

Om de prognoses van het Athena-model die zijn uitgedrukt in arbeidsvolumes geschikt te maken voor prognoses op basis van data uit de AKT en EBB, zijn de arbeidsvolume-prognoses van het CPB met behulp van de P/A-ratio's van het CPB omgerekend naar werkzame personen. De cijfers van het CPB, die gebaseerd zijn op de Nationale Rekeningen, komen echter niet volledig overeen met de cijfers uit de EBB. Om deze cijfers onderling vergelijkbaar te maken zijn de CPB-prognoses vermenigvuldigd met een factor, zodanig dat de beide cijferreeksen in 1991 aan elkaar gelijk zijn.

\section{Ontbrekende cijfers van kleine beroepssegmenten}

Verder zijn in de EBB-matrix beroepssegment $\mathrm{x}$ bedrijfstak aantallen beneden 2.500 gelijkgesteld aan 0 . Hierdoor verdwijnen in iedere bedrijfstak een aantal kleinere beroepen. Indien dit slechts voor één jaar het geval is, wordt de betreffende ontbrekende waarneming in principe gelijk gesteld aan 1.000. Beroepen die vaker dan een keer niet voorkomen in de tijdreeks zijn weggelaten. Er ontstaat door het ontbreken van informatie met betrekking tot deze lage aantallen een discrepatie tussen de aantallen werkzame personen per beroepssegment en het totaal per bedrijstak. Hiervoor is een extra restcategorie geïntroduceerd, waarin per bedrijfstak alle werkzame personen worden samengenomen die niet in een bepaalde beroep zijn geregistreerd. Voor deze extra categorie zijn ook prognoses gemaakt. Uiteraard bestaat er ook een discrepantie tussen de beroepstotalen en de som van de beroepenaantallen per bedrijfstak. De totale discrepantie is gelijk aan de discrepantie binnen de bedrijfstakken. In het model worden ook voor deze beroepsaandelen waarvan de bedrijfstak onbekend is prognoses gemaakt. Onder de veronderstelling dat de werkzame personen in een beroep waarvan de bedrijfstak onbekend is een vergelijkbare ontwikkeling doormaken als de personen met dit beroep waarvan de bedrijfstak wel bekend is, wordt de groei van de groep onbekenden geschat als afwikkeling van de ontwikkeling van deze groep personen waarvan de bedrijfstak wel bekend is. Vanwege de 
gehanteerde random-coëfficiënten-aanpak heeft deze veronderstelling een grote invloed op de prognoseresultaten.

\section{Ad hoc aanpassingen}

Omdat de hierboven beschreven methode op bepaalde punten tot implausibele resultaten leidde, zijn aan de algemene opzet een drietal ad hoc aanpassingen toegevoegd. De eerste aanpassing betreft de sector overig tertiair. In tegenstelling tot het Athena-model van het CPB, zijn in het beroepenmodel zowel de bank- en verzekeringsmaatschappijen als de overige dienstverlenende bedrijfstakken opgenomen. Hierdoor is deze bedrijfstak tamelijk heterogeen. In het verleden hebben de banken en de verzekeringsmaatschappijen een sterke groei doorgemaakt, wat impliceert dat de aan deze bedrijfstakken verbonden beroepssegmenten eveneens een sterke groei hebben doorgemaakt. Bij de schattingen komt dit tot uitdrukking in hoge parameterwaardes voor deze beroepssegmenten bij de trendvariabele. Deze groei wordt daardoor ook voor de komende jaren voorspeld. Het CPB verwacht echter een teruggang in de groei van het bank- en verzekeringswezen. Hierdoor zal de gehele bedrijfstak een teruggang ondervinden. De gevolgde methodiek impliceert dan echter dat de teruggang in de bedrijfstak, die veroorzaakt wordt door de banken en de verzekeringsmaatschappijen, consequenties heeft voor alle beroepssegmenten, en dat bovendien de aandelen van de beroepssegmenten die veel voorkomen bij de banken en de verzekeringsmaatschappijen een groter aandeel zullen krijgen vanwege hun groei in het verleden.

Om deze niet plausibele resultaten te voorkomen, is bij de bedrijfstak 'overige tertiair' de constante term als trendvariabele vervangen door de groei(prognoses) van het bank en verzekeringswezen. Hierdoor zullen de beroepssegmenten die een sterke groei in het verleden doormaakten, waarschijnlijk veroorzaakt door de groei bij deze instellingen, in de komende jaren volgens de prognoses een grotere krimp doormaken dan de andere beroepssegmenten.

Een tweede aanpassing op de algemene methodiek betreft het beroepssegment 'middelbare politie-, brandweer- en bewakingsberoepen' bij de overheid. Doordat volgens de CPB de overheid in zijn geheel een teruggang zal ondervinden, zou dit ook gelden voor het politiepersoneel. Het lijkt echter niet waarschijnlijk dat de overheid bij dit beroep zal gaan inkrimpen. Om deze reden is het aantal personen bij de overheid in bovengenoemd beroepssegment constant verondersteld. Voor de militairen had, gezien de overheidsplannen met betrekking tot defensie, een tegengestelde aanpassing tot de mogelijkheden behoord. De verwachting is echter dat, vanwege de afschaffing van de dienstplicht en vanwege de instelling van de luchtmobiele brigades, het totaal aantal beroepsmilitairen constant zal blijven.

De derde aanpassing die heeft plaatsgevonden betreft het beroepssegment 'overige' in de geconstrueerde restsector. Door een breuk in de data, waarschijnlijk veroorzaakt door veranderingen in de classificatiemethodiek, werd de trendparameter voor deze beroepssector onwaarschijnlijk hoog. Deze parameter is hierom op 0 gesteld.

Door het conservatieve karakter van de gevolgde voorspeltechniek bleek het niet nodig te zijn meer aanpassingen te maken dan deze drie. Voor de toekomst lijkt het zeer belangrijk oplossingen te bedenken voor de sterke heterogeniteit van met name de bedrijfssector 'overig tertiair'. De afsplitsing van de banken en de verzekeringsmaatschappijen is in dit opzicht een sterke verbetering. 
De uitbreidingsvraagprognoses per beroepssegment worden verder verbijzonderd naar prognoses per beroepsklasse. Dit gebeurt in een model dat qua opzet vergelijkbaar is met het model voor de beroepssegmenten. Met alleen de constante term als verklarende variabele van de groei wordt de afwijking van de groei van een beroepsklasse ten opzichte van het beroepssegment geschat. Ook dit gebeurt op basis van het random-coëfficiënten-model.

\section{Resultaten}

Op basis van de Athena-prognoses voor de periode 1993-1998 volgens (het behoudende scenario van het Centraal Economisch Plan 1993, CPB 1993) zijn middels het beroepenmodel prognoses gemaakt van de werkgelegenheidsontwikkeling per beroepssegment en beroepsklasse. In deze paragraaf worden de resultaten besproken van de voorspellingen per beroepssegment. De voorspelde ontwikkelingen per beroepsklasse zijn te vinden in ROA (1993b).

Tabel 6 bevat de resultaten van de prognoses van de vraag naar arbeid in de verschillende beroepssegmenten voor 1993 en 1998, geaggregeerd over de bedrijfssectoren. Vervolgens is deze verandering in de vraag uitgedrukt in een vijf-jaarlijkse groeivoet. De hoogste groei vindt plaats bij de middelbaar sociaal culturen beroepen (20\%). De grootste krimp bij lagere bouwmaterialen-, glas- en aardewerkberoepen $(-12 \%)$. De tabel laat ook zien dat meer dan 400.000 personen terechtkomen in de restcategorie, doordat niet gelijktijdig het beroepssegement en de bedrijfstak bekend zijn. Deze personen zijn overigens herverdeeld over de beroepen, zodat ze in tabel 6 zowel bij een van de 49 beroepen als in de restcategorie zijn terechtgekomen.

De vierde kolom van de tabel geeft aan welk deel van het voor 1998 voorspelde aantal personen via deze herverdeling is toeberekend aan het betreffende beroepssegment. De noemer is hierbij het aantal personen in 1993, zodat het aantal groter kan zijn dan 1. Vervolgens wordt per verklarende variabele aangegeven welke bijdrage deze leverde aan de verklaring van de beroepsomvang in 1998. 'vast' duidt op de verandering die zou hebben plaatsgevonden indien alleen de effecten van de veranderende bedrijfssectoromvangen zou zijn doorberekend. Vervolgens wordt aangegeven welke extra groei (of krimp) veroorzaakt is door respectievelijk de trendvariabele, de produktiecapaciteit (of de toegevoegde waarde), het aantal gewerkte uren en de werkloosheid. De som van al deze effecten is gelijk aan de mutatie in de derde kolom.

Opvallend is dat een groot deel van de verklarende kracht van het model veroorzaakt wordt door de trendvariabele. Kennelijk zijn de verklarende variabelen met een inhoudelijk karakter niet voldoende in staat om de veranderingen in de beroepenstructuur goed te verklaren. Door het grote belang van de trendvariabele zal het echter moeilijk zijn om een omslag van groei naar krimp tijdig te voorzien. Alleen indien deze omslag veroorzaakt wordt door veranderingen in de groei op bedrijfssectorniveau, kan in een model waarin de overige verklarende variabelen geen rol spelen toch een omslag voorzien worden. 


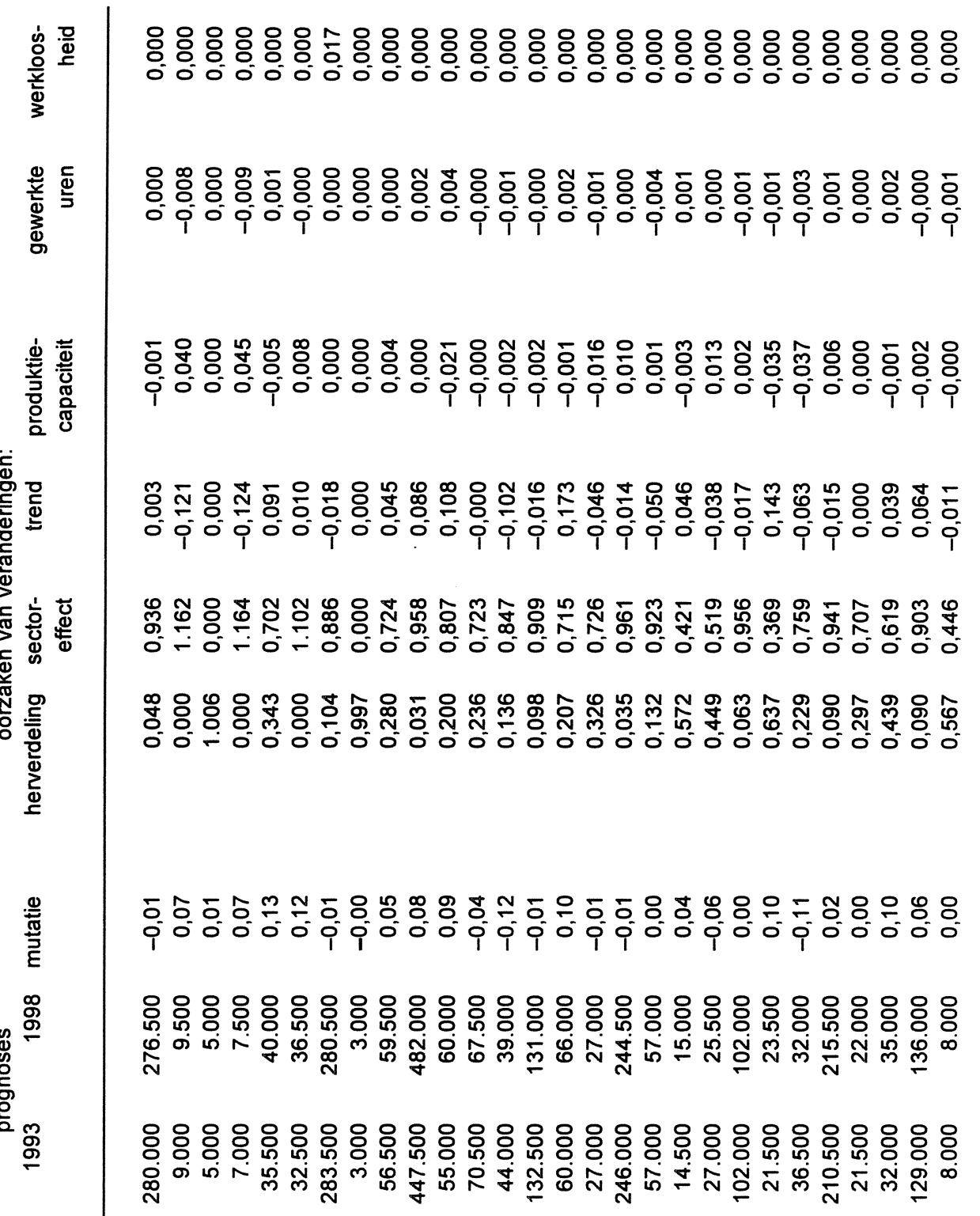

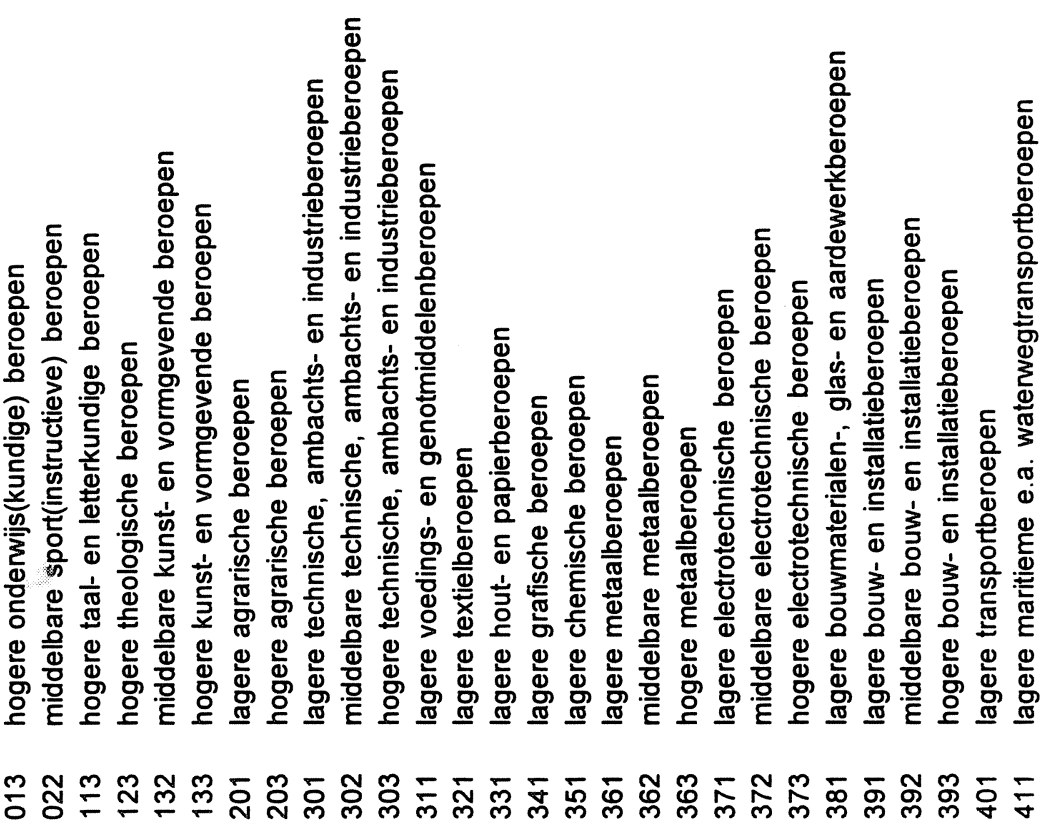




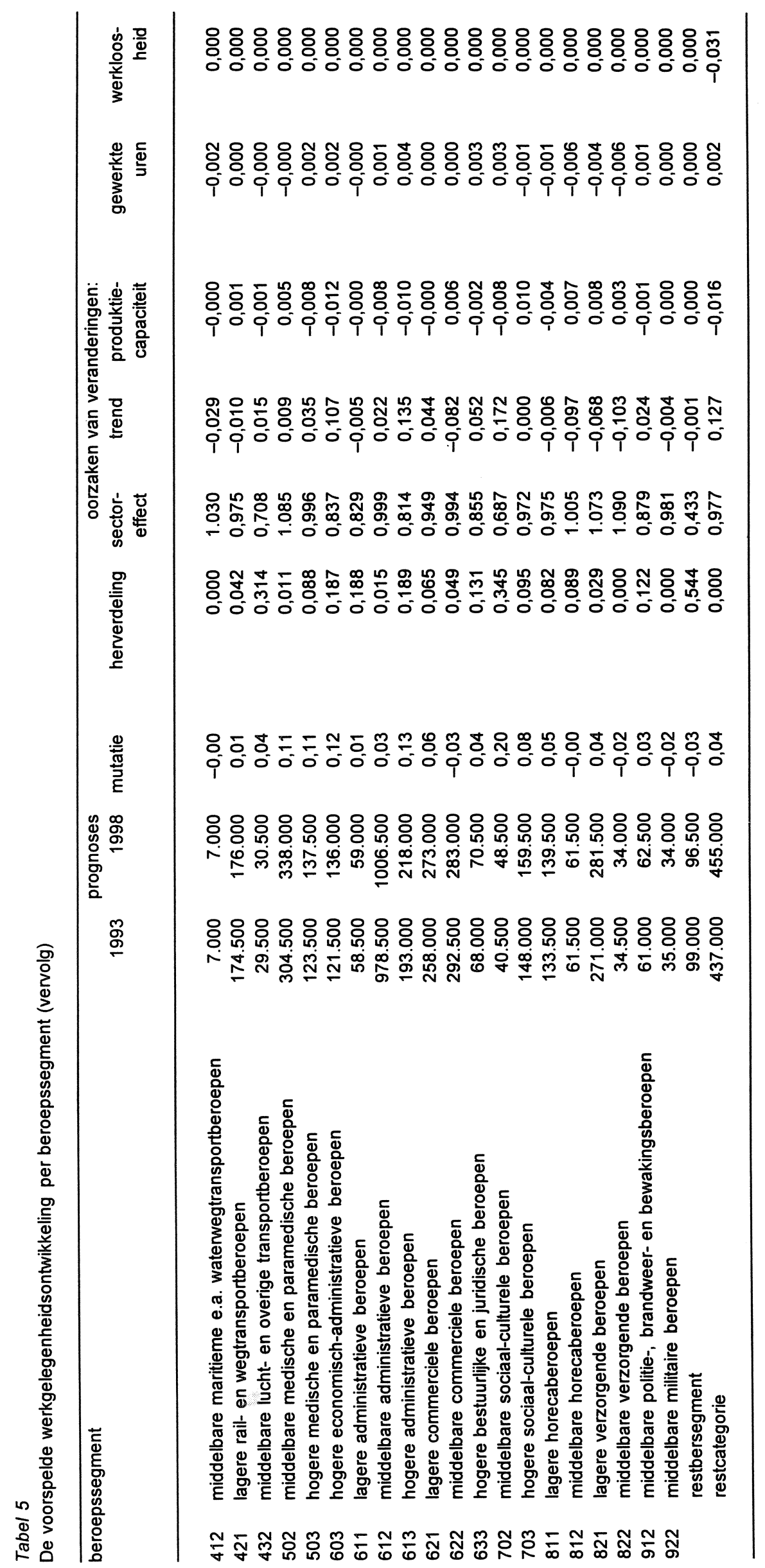




\section{Conclusies}

Bij het opstellen van een model ter verklaring van de beroepenstructuur van bedrijfstakken, om daarmee een prognose te kunnen maken van de vraag naar arbeid in bepaalde beroepssegmenten doen zich twee belangrijke problemen voor. Het eerste probleem betreft het feit dat de groeiprognoses voor de gehele bedrijfstak een nevenvoorwaarde opleggen aan de groei van de beroepssegmenten in die bedrijfstak. In Peeters (1990) wordt een oplossingsmethodiek voor dit verdeelprobleem aangedragen.

Een tweede probleem waar de werkgelegenheidsprognoses per beroepssegment mee te kampen hebben is de instabiliteit van de schattingsresultaten. Door de relatief korte tijdreeksen die beschikbaar zijn, zijn de standaardfouten van de parameterschattingen erg groot, terwijl een kleine afwijking van de parameter al grote gevolgen kan hebben voor de prognoseresultaten op basis van dit model. Om die reden is in deze studie een random-coëfficiënten-model voor de beroepenstructuur van bedrijfstakken opgezet, dat als voordeel heeft dat parameters, in het licht van hun onbetrouwbaarheid, conservatiever worden geschat. Hierdoor zijn de prognoses aanmerkelijk stabieler.

De random-coëfficiënten-methode blijkt op zich goed te functioneren. In de hier gevolgde aanpak is echter ieder bedrijfstak afzonderlijk geschat. Het ligt voor de hand om bij toekomstige verbeteringen van het model ook de relatie tussen parameters van een beroepssegment in de verschillende bedrijfstakken op een stochastische wijze te modelleren, zodat extra informatie van andere bedrijfstakken de kwaliteit van de schattingen verder kan verbeteren. Ook lijkt het zinvol na te gaan op welke wijze het mogelijk is rekening te houden met parameters die over de tijd veranderen. Zeker als de voorspeltermijn langer zou worden gemaakt, lijkt een dergelijke aanvulling van groot belang. Ten slotte blijkt opnieuw dat de verklaringste kracht van de verklarende variabelen buiten de trend klein is. Het is voor het verbeteren van de kwaliteit van de prognoses in het bijzonder van het vinden van aanslagpunten in de werkgelegenheidsontwikkeling van belang variabelen te vinden die beter in staat zijn de veranderingen van de beroepenstructuur te verklaren.

\section{Literatuur}

CPB (1990), ATHENA, Een bedrijfstakkenmodel voor de Nederlandse economie. CPB Monografie 30, Den Haag.

Crombrugghe, D. de en G. Dhaene (1991), Constrained Estimation of the Covariance Matrix of Random Coëfficiënts. Rijksuniversiteit Limburg, Faculteit der Economische Wetenschappen, RM 91-025, Maastricht.

Dekker, R.J.P., A. de Grip en J.A.M. Heijke (1988), Een verklaring van de beroepenstructuur van bedrijfstakken. ROA-W1988/2, Maastricht.

Dekker, R.J.P., A. de Grip, L. Borghans, A.G.M. Matheeuwsen, M.H. Wieling, E.J.T.A. Willems (1993), Methodiek van het informatiesysteem onderwijs-arbeidsmarkt 1993. ROA-W-1993/3, Maastricht

Draper, D.A.G., A. Nieuwenhuis en H.S. Tjan (1987), Vinsec, een model met zes productiesectoren van de Nederlandse economie voor de middellange termijn. CPB-Occasional paper 40, Den Haag.

Eijgenraam, C.J.J. en E.M. Verkade (1988), BETA, een bedriffstakkenmodel van de Nederlandse economie. CPBoccasional paper 44, Den Haag.

LDC (1994), Kansen op werk '98. Leeuwarden.

Lindley, R. (1994), 'A perspective on IER Forcasting Activities and Future Developments'. In Heijke (ed.) (1994), Forecasting the Labour Market by Occupation and Education. Boston.

Peeters, H.M.M. (1990), An Explanation of the Occupational and Educational Structure of Employment by Means of Multiniminal Logit. ROA-W-1990/4E, Maastricht. 
Researchcentrum voor Onderwijs en Arbeidsmarkt (1993a), De arbeidsmarkt naar opleiding en beroep tot 1998, ROA-R1993/10, Maastricht.

Researchcentrum voor Onderwijs en Arbeidsmarkt (1993b), De arbeidsmarkt naar opleiding en beroep tot 1998. Statistische bijlage. ROA-R-1993/10B, Maastricht.

Swamy, P.A.V.B. (1970), 'Efficient Inference in a Random Coëfficiënt Regression Model'. Econometrica 38, blz. 311-323.

Swamy, P.A.V.B. (1971), Statistical Inference in Random Coëfficiënt Regression Models. New York. 